\title{
New species and records of the mite genus Prolistrophorus (Acariformes: Listrophoridae) from rodents of the subfamily Sigmodontinae (Rodentia: Cricetidae)
}

\author{
Andre V. Bochkov ${ }^{1,2 *}$, Marcela Lareschi ${ }^{3}$ and Mauricio Barreto ${ }^{4}$ \\ ${ }^{1}$ Zoological Institute, Universitetskaya embankment 1, 199034 St. Petersburg, Russia; \\ ${ }^{2}$ Museum of Zoology, University of Michigan, 1109 Geddes Avenue, Ann Arbor, Michigan 48109-1079, USA; \\ ${ }^{3}$ Centro de Estudios Parasitológicos y de Vectores (CEPAVE), Calle 2, N 584, La Plata, Argentina; \\ ${ }^{4}$ Departamento de Microbiología, Universidad del Valle, Ave. 1 N \# 3N-35, Cali, Colombia
}

\begin{abstract}
Six fur-mite species of the genus Prolistrophorus Fain, 1970 (Acariformes: Listrophoridae) were recorded from Central and South American rodents of the subfamily Sigmodontinae (Rodentia: Cricetidae). Among them, Prolistrophorus (Aprolistrophorus) parabidentatus sp. nov. from Akodon azarae from Argentina and Prolistrophorus (Aprolistrophorus) tylomys sp. nov. from Tylomys nudicaudus from Guatemala are described as new for science. New hosts are recorded for the following species: Prolistrophorus (Prolistrophorus) grassii (Radford, 1954) from Zygodontomys brevicauda from Colombia, P. (P.) frontalis (Hirst, 1921) from Oligoryzomys sp. from Argentina, P. (P.) argentinus (Hirst, 1921) from Melanomys caliginosus, Akodon affinis from Colombia and Scapteromys aquaticus from Argentina, Prolistrophorus (Beprolistrophorus) hirstianus Fain, 1973 from Scapteromys aquaticus from Argentina.
\end{abstract}

\section{Keywords}

Fur-mites, Listrophoridae, Sigmodontinae, America, systematics, Prolistrophorus

\section{Introduction}

The mite genus Prolistrophorus Fain, 1970 (Acariformes: Listrophoridae) currently includes 27 species parasitizing the fur of New World mammals. Most of them are associated with rodents of the subfamily Sigmodontinae (Rodentia: Cricetidae) inhabiting Central and South America; three species have been recorded from rodents of the subfamily Neotominae (Cricetidae), three species - from rodents of the families Echimyidae (1 species), Muridae (1 species), and Ctenomyidae (1 species), and six species from a South American marsupial, Lestoros inca (Thomas, 1917) (Paucituberclata: Caenolestidae) (Fain and Lukoschus 1984; Bochkov 2010; Sikora and Bochkov 2012). We speculate that sigmodontines are, probably, the initial hosts of these mites, while their associations with other hosts could be explained by the host shifts (Bochkov 2011).

In this paper, descriptions of two new species and new hosts and localities for four previously known Prolistrophorus spp. are provided.

\section{Material and Methods}

Mites were obtained from three sources: samples collected by M. Lareschi from rodents captured in Argentina, samples collected by M. Barreto from rodents trapped by Dr. V. Rojas in Colombia, and samples from undetermined mite collection housed in the Zoological Institute (Saint Petersburg, Russia). The skins of rodents from Argentina and Columbia examined in this study are deposited at the National University of La Plata and at the University del Valle, respectively; their field numbers are catalogued. Mites were removed from the fur of rodent dry skins using fine, sharp forceps. Collected mite specimens were softened in hot Nesbitt's solution and mounted in Hoyer's medium. Drawings were made with a Leica microscope equipped with DIC optics and a camera lucida. In the descriptions below, the idiosomal setation follows Griffiths et al. (1990) with modifications of Norton (1998) concerning coxal setae. The leg setation follows Grandjean (1939). All measurements are in micrometres $(\mu \mathrm{m})$ and were taken as follow: body length $=$ the total length from the anterior extremity of the prescapular 
shield to the posterior border of the body; body width = width at the level of setae $s e$; length of dorsal shields = maximum length, measured along the median line of the shields; length of opisthosoma $=$ length from the posterior margins of trochanter IV insertions to the posterior border of the opisthosoma; length of the posterior legs = length from the most basal point of the trochanter to the apex of the tarsus, excluding pretarsus; tarsal length was measured without pretarsus. Host systematics follows Musser and Carleton (2005). Mite specimen depositories are cited using the following abbreviations:

UMMZ - Museum of Zoology, University of Michigan, Ann Arbor, MI, USA;

UNLP - National University of La Plata, La Plata, Argentina;

UV - University del Valle, Cali, Colombia;

ZISP - Zoological Institute, St. Petersburg, Russia.

\section{Systematics}

Family Listrophoridae Megnin et Trouessart, 1884 Subfamily Listrophorinae Megnin et Trouessart, 1884 Genus Prolistrophorus Fain, 1970

Subgenus Prolistrophorus Fain, 1970

Prolistrophorus (Prolistrophorus) grassii (Radford, 1954)

Listrophorus grassii Radford, 1954: 594, fig. 1.

Prolisrophorus grassii, Fain and Hyland 1974: 40.

Prolistrophorus (Prolistrophorus) grassii, Fain and Lukoschus 1984: 168, figs 1-3.

Material examined: 7 males and 7 females (AVB ZISP 14-0221005) from Zygodontomys brevicauda (Allen et Chapman, 1893) (Cricetidae: Sigmodontinae) (UV), COLOMBIA: Sucre Department, San Marcos Municipality, Correg. Santa Inés, Finca

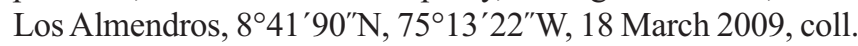
S. Arroyo and V. Rojas (field number SM-SI-SA 006); 5 males and 5 females - at ZISP, 2 males and 2 females - at UV.

Hosts and distribution: Oryzomys palustris (Harlan, 1837) (Cricetidae: Sigmodontinae) [type host] from USA (Alabama, Georgia, and Florida) (Radford 1954; Fain and Hyland 1974), Zygodontomys brevicauda [new host] from Colombia (present paper), and Synaptomys cooperi Baird, 1857 (Cricetidae: Arvicolinae) from USA (Indiana, Virginia, and Iowa) (Fain and Hyland 1974). Mites of this species on Synaptomys cooperi had, probably, shifted from sigmodontines.

\section{Prolistrophorus frontalis (Hirst, 1921)}

Listrophorus frontalis Hirst, 1921: 366, fig. 10.

Prolistrophorus frontalis, Fain 1970: 280; Fain and Hyland 1974: 11, figs $1-4$.

Prolistrophorus (Prolistrophorus) frontalis, Fain and Lukoschus 1984: 164; Fain and Estebanes 1996a: 181.

Material examined: 19 males and 16 females (AVB ZISP 140221-009) from Oligoryzomys fulvescens (Saussure, 1860) (Cricetidae: Sigmodontinae) (UNLP), ARGENTINA: Buenos
Aires Province, Estancia El Destino, $35^{\circ} 12^{\prime} 05^{\prime \prime} \mathrm{S}, 57^{\circ} 38^{\prime} 80^{\prime \prime} \mathrm{W}$, 14 August 2010, coll. A. M. Abba, L. Pagano and M. R. Robles (field number ROB 400); 15 males and 10 females - at ZISP, 2 males and 4 females - at UNLP, 2 males and 2 females - at UMMZ.

Hosts and distribution: Oligoryzomys delticola (Thomas, 1917) (Cricetidae: Sigmodontinae) [type host] from Brazil (Parana) (Hirst 1921; Fain 1973b), Oligoryzomys fulvescens from Mexico (Veracruz) (Fain and Estebanes 1996a) and Argentina (present paper).

Prolistrophorus (Prolistrophorus) argentinus (Hirst, 1921) Listrophorus argentinus Hirst, 1921: 366, fig. 10 C, D. Prolistrophorus argentinus, Fain 1973b: 13, figs 5-8.

Prolistrophorus (Prolistrophorus) argentinus, Fain and Lukoschus 1984: 164; Fain et al. 1996b: 58; Sikora and Bochkov 2013: 392.

Prolistrophorus hirsti Fain, 1970: 280.

Material examined: 1 male and 3 females (AVB ZISP 14-0221001) from Melanomys caliginosus (Tomes, 1860) (Cricetidae: Sigmodontinae) (UV), COLOMBIA: Valle del Cauca Department, Palmira Municipality, Ingenio Manuelita, $3^{\circ} 34^{\prime} 22^{\prime \prime} \mathrm{N}$, $76^{\circ} 16^{\prime} 43^{\prime \prime} \mathrm{W}, 28$ March 2009, coll. V. Rojas (field number HPR 130); 1 male and 1 female (AVB ZISP 14-0221-002) from same host (UV) and locality, 21 March 2009, coll. V. Rojas (field number HPR 112); 1 male and 1 female (AVB ZISP 140221-003) from same host (UV) and locality, 2 April 2009, coll. V. Rojas (field number HPR 141); 1 male (AVB ZISP 140221-004) from same host (UV) and locality, 22 March 2009, coll. V. Rojas (field number HPR 114); 12 males and 4 females (AVB ZISP 14-0221-006) from Akodon affinis (Allen, 1912) (Cricetidae: Sigmodontinae) (UV), COLOMBIA: Valle del Cauca Department, Palmira Municipality, Ingenio Manuelita, $3^{\circ} 34^{\prime} 22^{\prime \prime} \mathrm{N}, 76^{\circ} 16^{\prime} 43^{\prime \prime} \mathrm{W}, 29$ March 2009, coll. V. Rojas (field number HPR 136); 1 male (AVB ZISP 14-0221-007) from same host (UV) and locality, 21 March 2009, coll. V. Rojas (field number HPR 111); 2 males and 2 females - at UV, 2 males and 2 females - at UMMZ, other - at ZISP; 2 males and 9 females (AVB ZISP 14-0221-011) from Scapteromys aquaticus Thomas, 1920 (Cricetidae: Sigmodontinae) (UNLP), ARGENTINA: Buenos Aires Province, Los Talas, 345'ㄱ, 5748'W, 5 April 1995, coll. M. Lareschi and G. Navone (field number T 004); 2 females - at UNLP, other - at ZISP.

Hosts and distribution: Scapteromys aquaticus [type host] from Argentina (Hirst 1921; Fain 1973b; present paper), Oryzomys subflavus (Wagner, 1842) (Cricetidae: Sigmodontinae) from Brazil (Minos Gerais and Belo Horizonte) (Fain et al. 1996b), Holochilus brasiliensis (Desmarest, 1819) (Cricetidae: Sigmodontinae) and Holochilus chacarius (Thomas, 1906) from Argentina (Entre Rios and Formosa, respectively) (Sikora and Bochkov 2012), Melanomys caliginosus [new host] and Akodon affinis [new host] - from Colombia (present paper).

Remark. Kunsia tomentosus (Lichtenstein, 1830) (Cricetidae: Sigmodontinae) was originally mentioned as the type host 


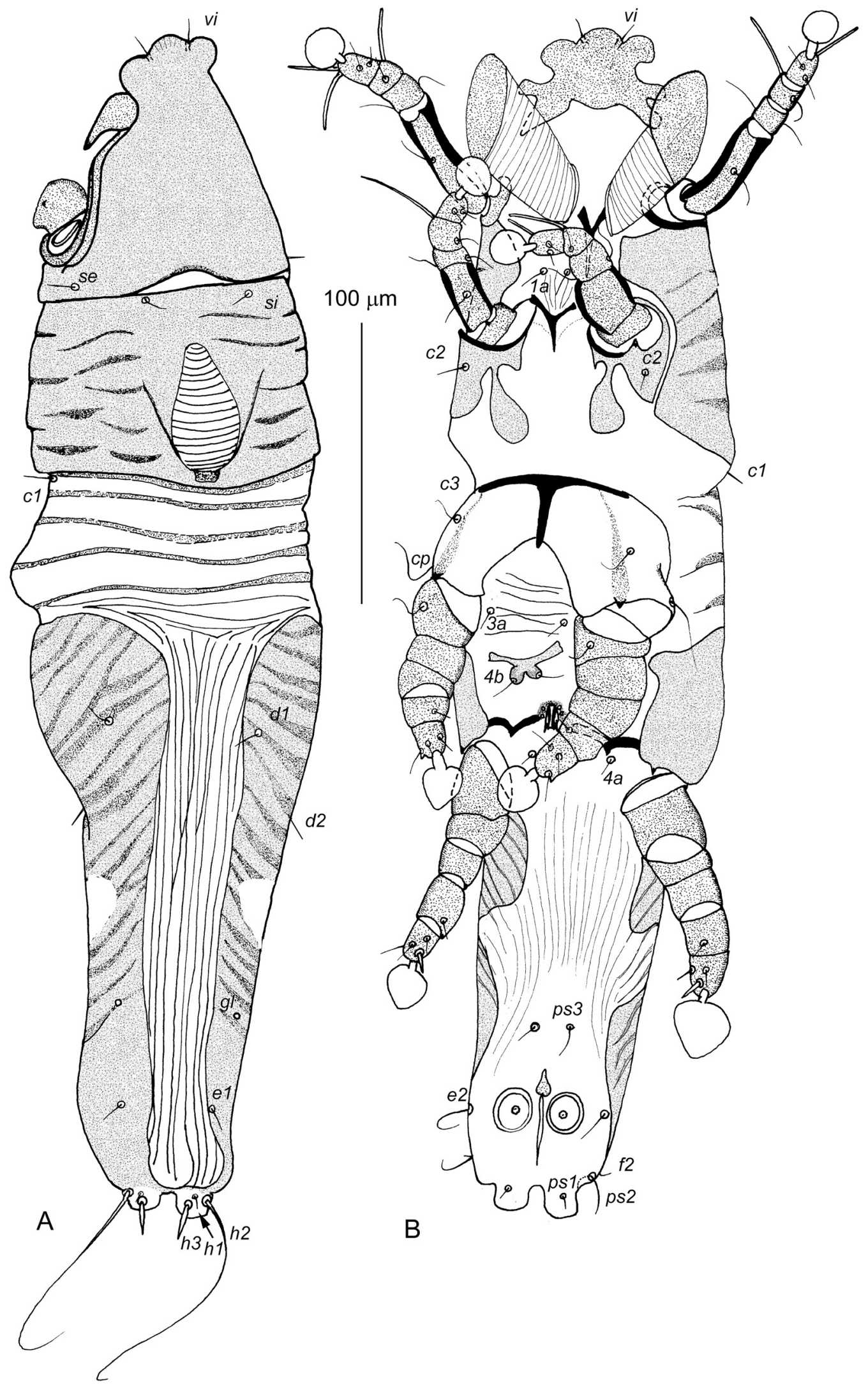

Fig. 1. Prolistrophorus parabidentatus sp. nov., male. A - in dorsal view; $\mathbf{B}$ - in ventral view 


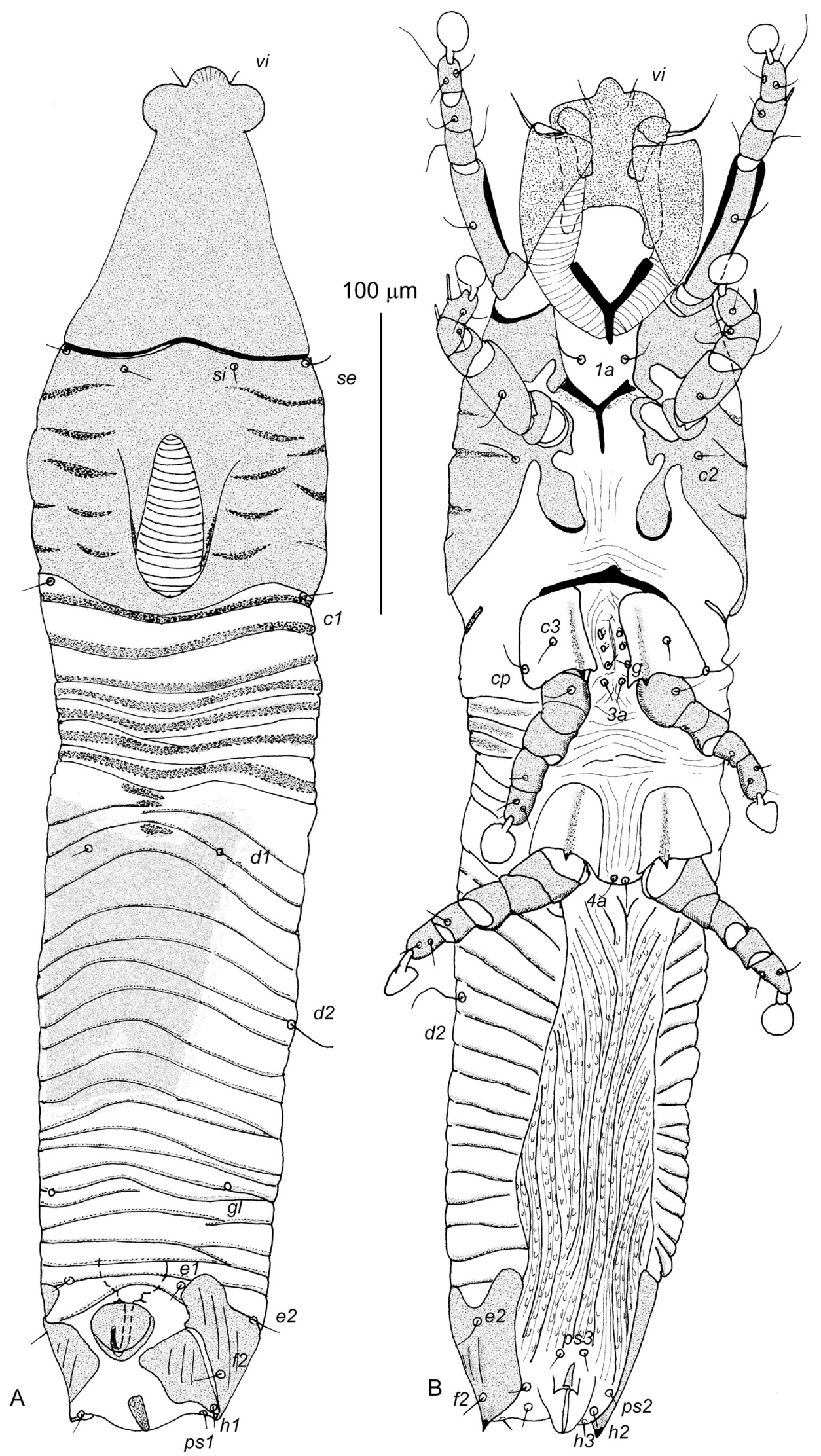

Fig. 2. Prolistrophorus parabidentatus sp. nov., female. A - in dorsal view; $\mathbf{B}$ - in ventral view 
of this species (Hirst 1921; Fain 1973b). In the recent works, however, records of this species from Argentina are considered as misidentification for Scapteromys aquaticus (Musser and Carleton 2005; Barquez et al. 2006).

\section{Subgenus Aprolistrophorus Fain, 1980}

Prolistrophorus (Aprolistrophorus) parabidentatus sp. nov. (Figs 1-3)

Male (holotype, Figs 1, 3A-E). Body 410 long (400-415 in 10 paratypes), 110 wide (105-110). Prescapular shield 80 long
(80-90). Posterior margin of prescapular shield distinctly sclerotised, not interrupted medially. Postscapular shield 75 long (70-80), with 8-9 pairs of thickened dark lateral transverse markings present posterior to seta si bases, none of them reaching median frame. Median frame (not sclerotised median area in postscapular shield) closed, well developed - about 50 long and 20 wide. Median apodeme present. Soft cuticle of median frame covered by numerous (14-16) transverse striae. Hysteronotal shield 200 long (200-210), occupying most of hysteronotum. Lateral margins of hysteronotal shield with incision at midlevel. This shield covered by regularly spaced
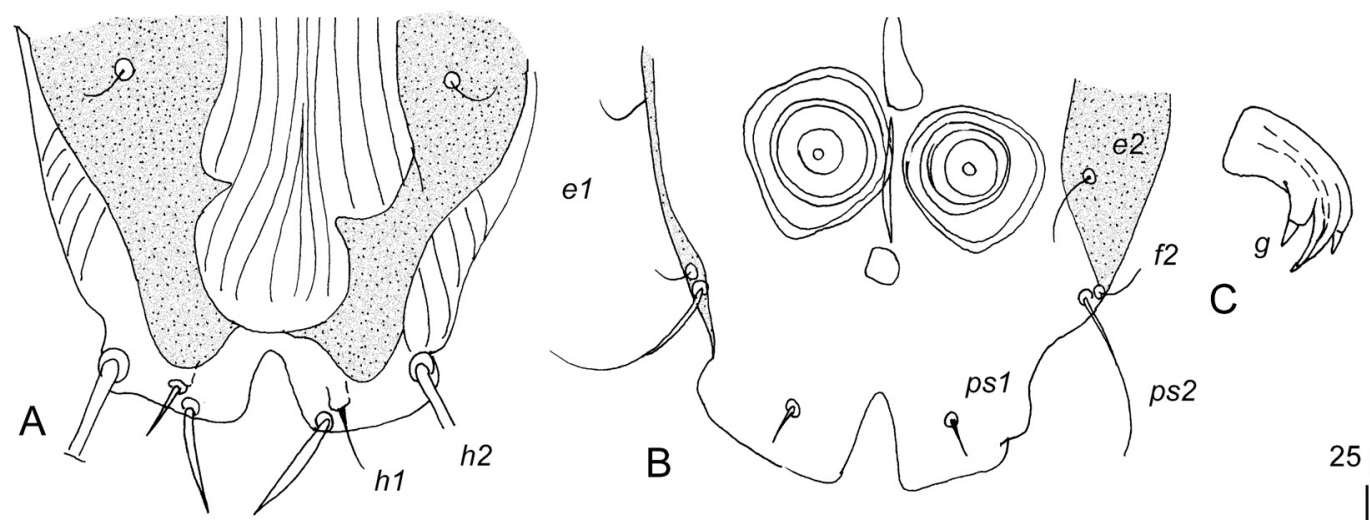

III

h3
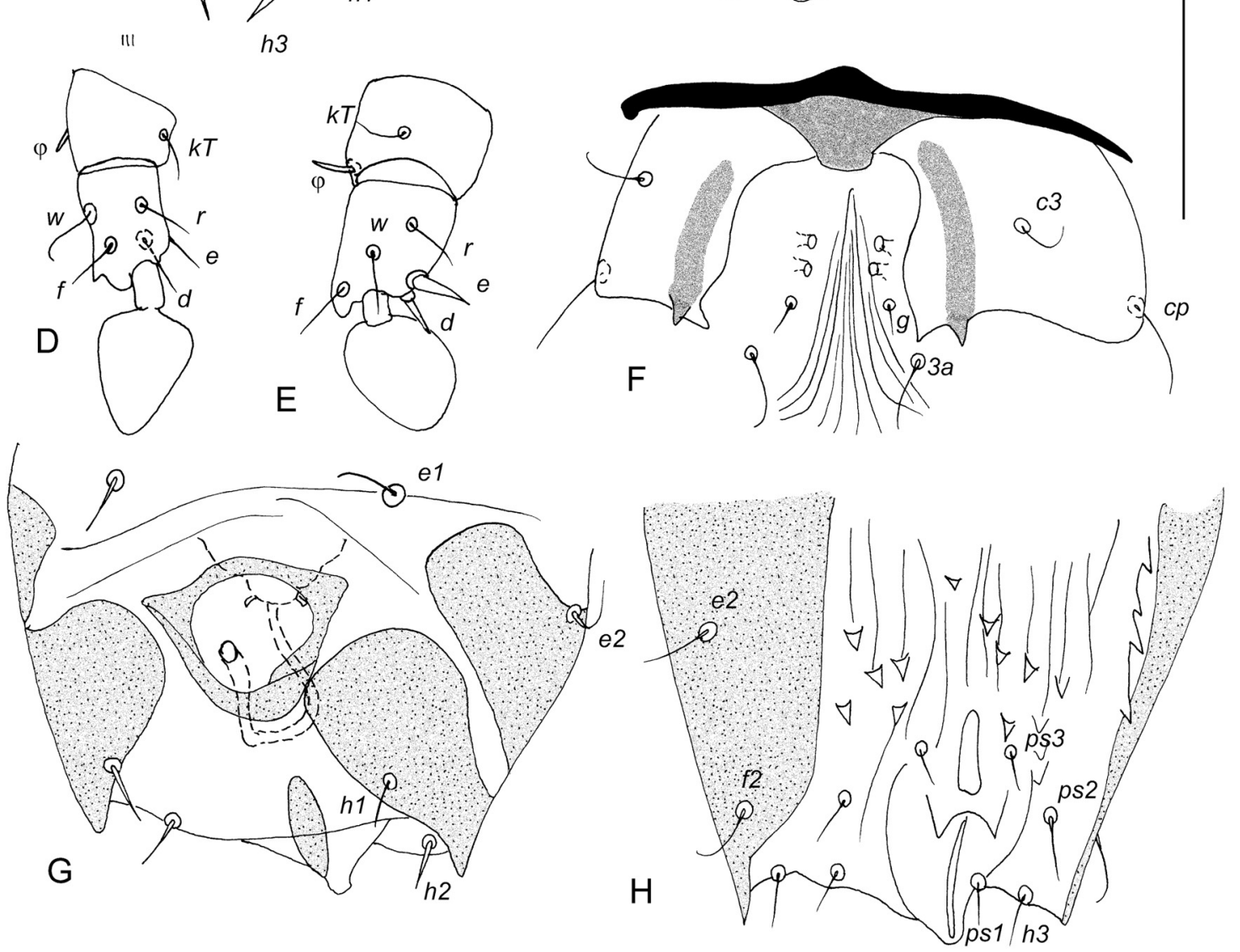

Fig. 3. Prolistrophorus parabidentatus sp. nov., details. A - posterior end of male opisthosoma in dorsal view; $\mathbf{B}-$ same in ventral view; $\mathbf{C}$ - aedeagus; D - tarsus III of male in ventral view; $\mathbf{E}$ - tarsus IV of male in ventral view; $\mathbf{F}$ - vulva; $\mathbf{G}$ - posterior end of female opisthosoma in dorsal view; $\mathbf{H}$ - same in ventral view 
thickened dark oblique markings, most posterior marking situated at level of hysteronotal glands openings $g l$ and distinctly posterior to lateral incisions. Maximum distance between lateral parts of hysteronotal shield about 25 . Soft cuticle between these parts with 7-10 longitudinal striae. Area between postscapular and hysteronotal shields about 50 long, covered by 4-5 transverse distinctly sclerotised striae. Opisthosoma 135 long (130-140). Opisthogaster without scales, longitudinally striated. Coxal fields III slightly dilated. Apodemes IIIb greatly reduced. Ventral paramedian shields posterior to coxal fields IV absent. W-shaped sclerites connecting genital apparatus and coxal fields IV present. Setae $4 b$ situated on basally fused peduncles, between levels of aedeagus and leg III insertions. Penis about 8 long, distinctly curved; setae $g$ flanking apex of penis. Pregenital apodeme absent. Adanal suckers oval, their diameter about 12. Minimal distance between these suckers 5 long. Opisthosomal lobes weakly developed, terminal cleft about 10 long, lobes about 15 wide, without triangular projections. Setae $h 2$ about 75 long; setae $h 3$ present, narrowly lanceolate, about 12 long. Legs III and IV subequal (about 80 long), shorter than opisthosoma. Tarsi III and IV about 15 long. Tarsi III and IV with short dorso-apical projection. Setae $f \mathrm{IV}$ filiform, setae $d \mathrm{IV}$ and $e \mathrm{IV}$ thickened spine like. Solenidia $\omega 1$ I, II about 8 long, $\omega 3$ I about 17 long, $\varphi$ I, II about 35 long.

Female (10 paratypes, Figs 2, 3F-H). Body 450-475 long, 95-100 wide, not curved ventrally in anterior third. Prescapular shield 80-85 long. Postscapular shield 85-90 long, covered by $7-8$ short lateral thickened markings. Median frame closed, well developed, - about 50 long and 20 wide. Median apodeme present. Soft cuticle of median frame covered by numerous (19-21) transverse striae. Hysteronotal shield 95-100 long, crossed by 9-10 transverse body striae. Anterior margin of this shield located slightly anterior to level of seta $d 1$; area between posterior margin of hysteronotal shield and level of hysteronotal glands crossed by 3-4 transverse body striae. Area between postscapular and hysteronotal shields about 70 long, covered by 7-8 transverse striae, distinctly sclerotised. Hysteronotal shield not fused with sclerotisation of coxal fields IV. Opisthosoma about 170 long. Opisthosomal dorsum covered by regularly spaced transverse striae and posteriorly with pair of short obliquely dissected lateral shields about 30 long and small median shield bearing opening of bursa copulatrix and situated between lateral shields. Lateral opisthosomal shields each with very short triangular projection; these projections flanking posterior margin of opisthosoma. Spermatheca located at level of posterior median shield of opisthosoma. Setae $e 2$ and $f 2$ located on lateral opisthosomal shields. Setae $h 2$ short, about 5 long, subequal in length to other opisthosomal setae. Apodemes IIa fused to each other into Yshaped sclerite. Cuticle between coxal fields II not striated. Derivatives of apodemes IIIa fused at inner tips, strongly sclerotised. Setae $4 b$ absent. Opisthogaster covered by small scales confined to longitudinally striated cuticle. Legs III and IV subequal, 60-65 long. Setae $d$ III and $d$ IV 2.5 times shorter than respective tarsi without pretarsus. Solenidia $\omega /$ I, II about 7 long, $\omega 3 \mathrm{I}$ about 10 long, and $\varphi \mathrm{I}$, II about 12 long.

Type material: Holotype male (ZISP T-L-8), 26 male and 19 female paratypes (AVB ZISP 14-0221-008) from Akodon azarae (Fischer, 1829) (Cricetidae: Sigmodontinae) (UNLP), ARGENTINA: Buenos Aires Province, Estancia El Destino, $35^{\circ} 12^{\prime} 05^{\prime \prime} \mathrm{S}, 5^{\circ} 38^{\prime} 80^{\prime \prime} \mathrm{W}, 14$ August 201, coll. A. M. Abba, L. Pagano and M. R. Robles (field number ROB 401); 6 male and 4 female paratypes (AVB ZISP 14-0228-001) from same host (UNLP), ARGENTINA: Buenos Aires Province, Balneario La Balandra, 3456'S, 5742’ W, 7 November 2006, coll. M. R. Robles and C. Galliari (field number RR18).

Type depositions: Holotype, 22 male, and 15 female paratypes - at ZISP; 5 male and 5 female paratypes - at UNLP; 5 male and 5 female paratypes - at UMMZ.

Hosts and distribution: This species is known only from Akodon azarae from Argentina.

Etymology: The specific epithet derives from the similarity of this species with Prolistrophorus (A.) bidentatus Fain et Lukoschus, 1984.

Differential diagnosis: Prolistrophorus (A.) parabidentatus sp. nov. is most similar to $P$. (A.) bidentatus from Lestoros inca from Peru (Fain and Lukoschus 1984). In both sexes of these species, the median frame of the postscapular shield is closed and large, the transverse striae between the postscapular and hysteronotal shields are distinctly sclerotised, the postscapular shield bears laterally dark and thick markings, not reaching the median frame; in males, the hysteronotal shield is covered by a few (6-9 pairs) thickened dark lateral transverse markings, the posterior lobes are without projections, setae $h 3$ are narrowly lanceolate, the opisthogaster is without scales and longitudinally striated, tarsus III with short dorso-apical projection; in females, the opisthonotum is covered by regularly spaced transverse lines, the posterior part of the opisthosoma has the two short lateral shields and one median shield, the posterior extremity of the opisthosoma is flanked by two short conical projections, the longitudinally striated part of the opisthogaster bears numerous small scales, and the spermatheca is situated distinctly posterior to the hysteronotal gland openings. These species differ from each other by the following features. In males of $P$. parabidentatus, coxal fields III are slightly thickened, the hysteronotal shield is covered by thickened oblique markings, the posteriormost marking is situated distinctly posterior to the lateral incision at the level of the hysteronotal gland openings; in females, the body is not curved ventrally in the anterior third and the posterior margin of the hysteronotal shield is situated distinctly anterior to the level of the hysteronotal gland openings. In males of P. bidentatus, coxal fields III are strongly thickened, the hysteronotal shield is covered by tine oblique striae, the posteriormost stria is situated distinctly anterior to the hysteronotal glands openings (approximately at the level of the lateral incisions); in females, the body is curved ventrally in the anterior third and the posterior margin of the hysteronotal shield is situated distinctly posterior to the level of the hysteronotal gland openings. 


\section{Prolistrophorus (Aprolistrophorus) tylomys sp. nov. (Figs 4, 5)}

Male (holotype, Figs 4A, 5A, B). Body 430 long (420-425 in 2 paratypes), 90 wide in lateral view at level of postscapular shield (90-95). Prescapular shield 100 long (95-100). Posterior margin of prescapular shield distinctly sclerotised, not interrupted medially. Postscapular shield 72 long (6570), with 5-6 pairs of thickened dark transverse lines present immediately posterior to seta $s i$ bases, reaching median incision. Median frame closed, almost as long as postscapular shield. Median apodeme present. Soft cuticle of median incision covered by numerous (19-20) transverse striae. Hysteronotal shield very short, situated in posterior half of opisthosoma, 80 long (75-80). Lateral margins of hysteronotal shield without incisions. Lateral parts of this shield connected by distinct anterior bridge. Anterior part of hysteronotal shield covered by 4 regularly spaced dark oblique striae, posteriormost stria situated anterior to level of setae $e 2$, and 2 short lines at level of setae $e 2$. Soft cuticle between lateral parts of hysteronotal shield with transverse striae. Area between postscapular and hysteronotal shields about 170 long, covered by 25-27 weakly sclerotised striae. Opisthosoma 130 long (125-130). Opisthogaster without scales, transversely striated. Coxal fields III not dilated. Apodemes IIIb greatly reduced. Ventral paramedian shields posterior to coxal fields IV absent. W-shaped sclerites connecting genital apparatus and coxal fields IV present. Setae $4 b$ situated on soft cuticle between transverse levels of aedeagus and leg III insertions. Penis about 7 long, straight; setae $g$ absent. Pregenital apodeme absent. Adanal suckers oval, their diameter about 10. Opisthosomal lobes weakly developed, about 15 long, each with small triangular lateral projection. Setae $h 2$ about 85 long; setae $h 3$ present, membranous, widely foliate, about 10 long. Legs III and IV subequal (about 95 long), shorter than opisthosoma. Tarsi III and IV about 25 long. Tarsi III without dorso-apical projection; tarsi IV with distinct dorso-apical projection. Setae fIV filiform, setae $d \mathrm{IV}$ represented by alveoli, $e \mathrm{IV}$ thickened spine like. Solenidia $\omega 1$ I, II about 12 long, $\omega 3$ I about 25 long, $\varphi$ I, II about 50 long.

Female (2 paratypes, Figs 3B, 4C). Body 475-485 long, about 150 wide in lateral view, not curved ventrally in anterior third. Prescapular shield about 110 long. Postscapular shield 85-87 long, with 5-6 pairs of thickened dark transverse lines present immediately posterior to seta si bases, reaching median incision. Median frame closed, almost as long as postscapular shield. Median apodeme present. Soft cuticle of median incision covered by numerous (22-25) t regularly spiced transverse striae. In posterior third of this shield 5-6 short median striae inserted between these long striae. Hysteronotal shield covering almost entire hysteronotum, crossed by 25-28 transverse striae. Anterior margin of this shield located at level of leg III insertions. Area between postscapular and hysteronotal shields $50-65$, covered by 4 transverse moderately sclerotised striae. Hysteronotal shield not fused with sclerotized areas of coxal fields IV. Opisthosoma about 185 long. Posterior margin of opisthosoma without lateral projections. Spermatheca located slightly anterior to level of setae $e 2$. Setae $h 2$ short, about 5 long, subequal in length to other opisthosomal setae. Apodemes IIa fused to each other. Cuticle between coxal fields II striated. Derivatives of apodemes IIIa fused at inner tips, strongly sclerotised. Setae $4 b$ absent. Opisthogaster covered by small scales confined to longitudinally striated cuticle. Legs III and IV subequal, about 65 long. Setae $d \mathrm{III}$ and $d \mathrm{IV} 2.5$ times shorter than respective tarsi without pretarsus. Solenidia $\omega 1$ I, II about 7 long, $\omega 3$ I about 10 long, and $\varphi \mathrm{I}$, II about 15 long.

Type material: Holotype male (ZISP T-L-9), 2 male and 2 female paratypes (AVB ZISP 14-1303-001) from Tylomys nudicaudus (Peters, 1866) (Cricetidae: Tylomyinae), GUATEMALA: Alta Verapaz, no other data.

Type depositories: Whole material - at ZISP.

Hosts and distribution: This species is known only from Tylomys nudicaudus from Guatemala (present paper).

Etymology: The specific epithet derives from the generic name of the host and is a noun in apposition.

Differential diagnosis: Prolistrophorus (A.) tylomys sp. nov. is the first listrophorid species described from the cricetid subfamily Tylomyinae. These mites have a peculiar morphology easily distinguishing them from other representatives of the genus Prolistrophorus. In both sexes of $P$. tylomys, the median incision of the postscapular shield is almost as long as this shield; in males, the genital setae are absent, the hysteronotal shield is very short, widely separated medially but remaining connected in the anterior part by a transverse bridge, tarsal setae $d \mathrm{IV}$ are represented by alveoli. We tentatively include this species to the subgenus Aprolistrophorus based on the male hysteronotal shield separated posteriorly, the opisthosomal lobes separated from each other, and the female hysteronotal shield stretching anteriorly beyond the level of setae $d 1$. Within Aprolistrophorus, the new species is most similar to $P$. (A.) akodon from Necromys urichi (Allen et Chapman, 1897) (Cricetidae: Sigmodontinae) from Venezuela (Fain and Lukoschus 1982), Necromys lasiurus (Lund, 1840) from Brazil (Fain et al. 1996b), and Akodon montensis (Thomas, 1913) (Cricetidae: Sigmodontinae) from Argentina (Sikora and Bochkov 2012). In males of both species, coxal fields III are not dilated, tarsi III are without the dorso-apical projection, the opisthosomal lobes are ending with the short triangular process; in females, the hysteronotal shield covers most part of the hysteronotum. In addition to the above mentioned differences, these species differ from each other by the following features. In both sexes of $P$. tylomys, the postscapular shield is covered by long dark lines interrupted by the median incision; in males, striae between the postscapular and hysteronotal shields are weakly sclerotised, setae $h 3$ are membranous; in females, the posterior end of the opisthosoma is devoid of the dorso-lateral shields. In both sexes of P. akodon, the postscapular shield is covered by short spindle-like mark- 


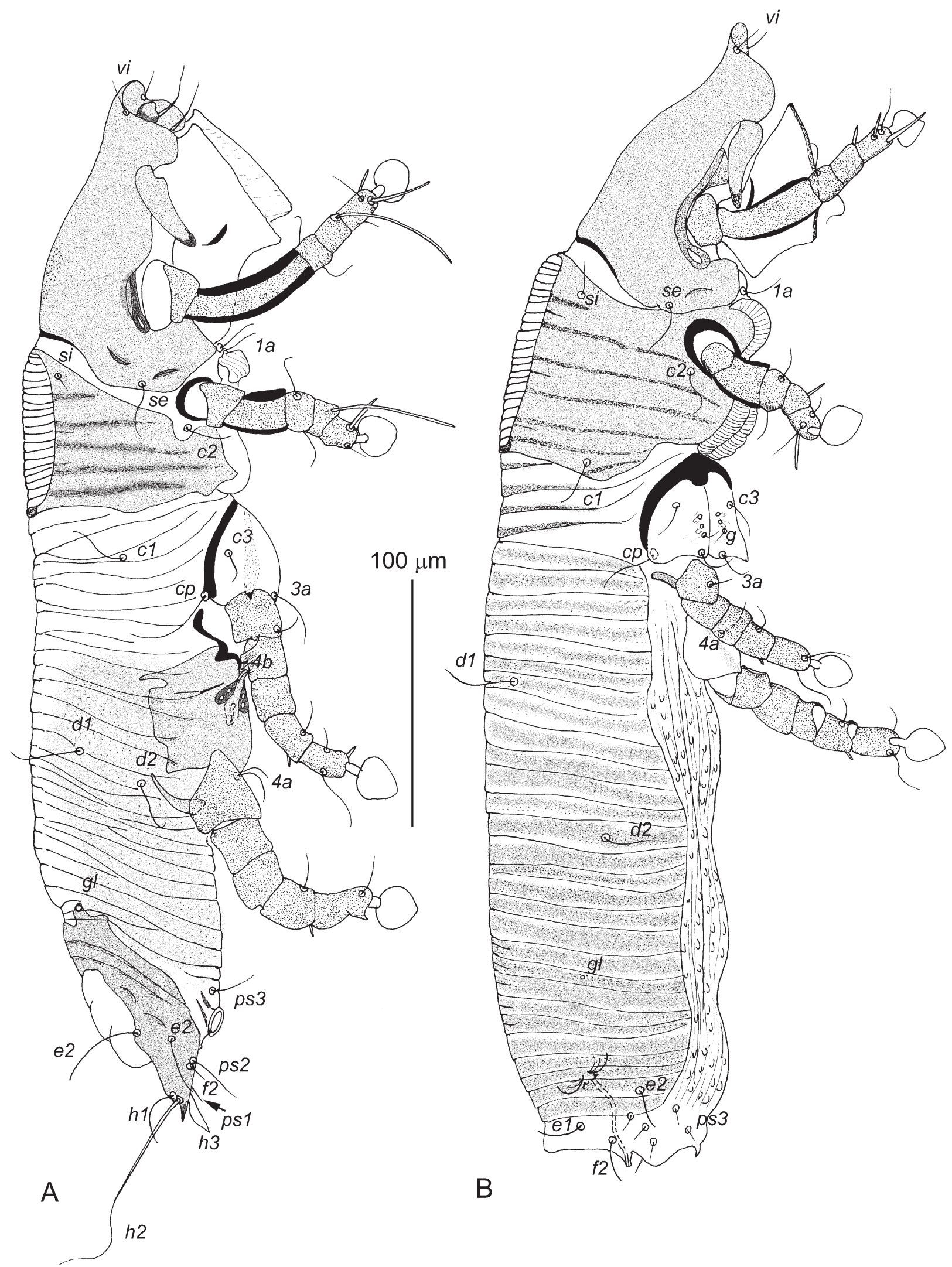

Fig. 4. Prolistrophorus tylomys sp. nov. A - male in lateral view; $\mathbf{B}$ - female in lateral view 


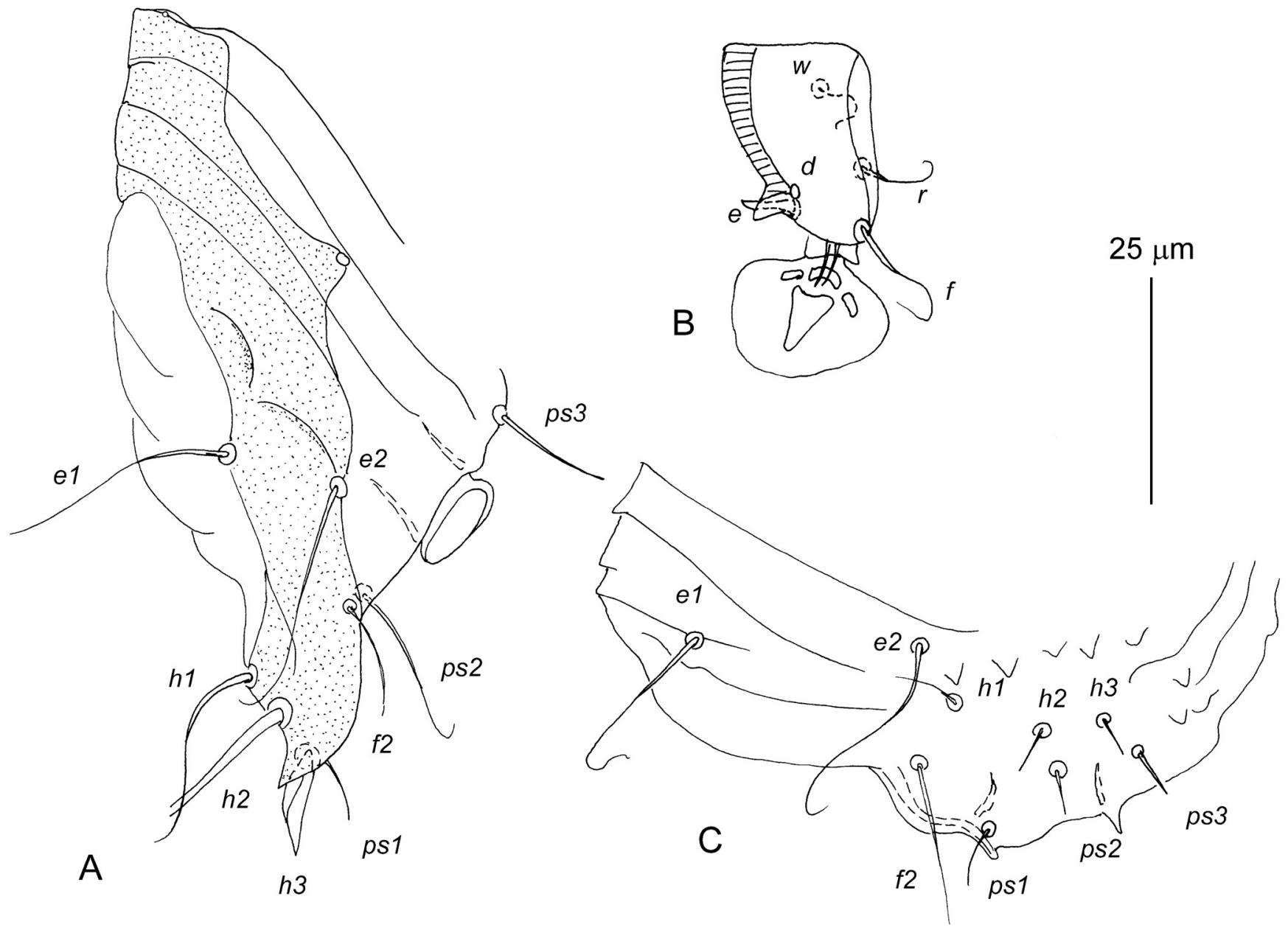

Fig. 5. Prolistrophorus tylomys sp. nov. A - dorsal end of male opisthosoma in lateral view view; B - tarsus IV of male in dorsal view; $\mathbf{C}$ - dorsal end of female opisthosoma in lateral view

ings not interrupted by the median incision; in males, striae between the postscapular and hysteronotal shields are distinctly sclerotised, setae $h 3$ are stick-like; in females, the posterior end of the opisthosoma has a pair of the dorso-lateral shields.

\section{Subgenus Beprolistrophorus Fain, 1980}

Prolistrophorus (Beprolistrophorus) hirstianus Fain, 1973 Prolistrophorus hirstianus Fain, 1973a: 331, 1973b: 23, figs 13-16.

Prolistrophorus (Beprolistrophorus) hirstianus, Fain and Lukoschus 1984: 165.

Material examined: 7 males and 5 females (AVB ZISP 14-0221-010) from Scapteromys aquaticus Thomas, 1920 (Cricetidae: Sigmodontinae) (UNLP), ARGENTINA: Buenos Aires Province Hudson, $34^{\circ} 45^{\prime} \mathrm{S}, 58^{\circ} 06^{\prime} \mathrm{W}, 18$ April 1995 , coll. M. Lareschi and G. Navone (field number HO18); 3 males and 5 females (AVB ZISP 14-0221-011) from same host (UNLP), ARGENTINA: Buenos Aires Province, Los Talas, $34^{\circ} 54^{\prime} \mathrm{S}, 57^{\circ} 48^{\prime} \mathrm{W}, 5$ April 1995, coll. M. Lareschi and G.
Navone (field number T004); 1 male and 1 female (AVB ZISP 14-0221-012) from same host (UNLP), ARGENTINA: Buenos

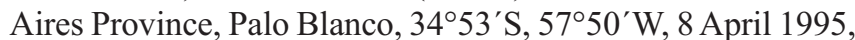
coll. M. Lareschi and G. Navone (field number PB004); 2 males and 2 females - at UNLP, other material - at ZISP.

Hosts and distribution: Scapteromys aquaticus (originally mentioned as Kunsia tomentosus [type host]) from Argentina (Fain 1973a, b; present paper).

Acknowledgements. We thank Dr. Vladimir Rojas, who trapped and identified Colombian rodents used in this study, and María Elena Burbano, who helped to collect mites from them. Concerning specimens from Argentina, we thank G. Navone (CEPAVE) for her help with field work; to M. R., Robles (CEPAVE) for providing rodents for their examination; to C. Galliari (CEPAVE) for host identification and providing literature on rodents; to S. Yranek (CEPAVE) for her help in collecting mites; to I. Olivares and D. Verzi (UNLP) for allowing examining rodents housed at the Museum of the La Plata University, Argentina. We thank Dr. S.V. Mironov (ZISP) for critical comments on the manuscript. This research was supported by the Russian Foundation for Basic Research (Grant No 13-04-00608a) to AVB and by the Belgian National Focal Point to the Global Taxonomy Initiative to MB. 


\section{References}

Barquez R.M., Díaz M.M., Ojeda R.A. 2006. Mamíferos de Argentina. Sistemática y distribución. SAREM, Mendoza, Argentina, $359 \mathrm{pp}$.

Bochkov A.V. 2010. A review of mammal associated Psoroptidia (Acariformes: Astigmata). Acarina, 18, 99-260.

Bochkov A.V. 2011. Evolution of parasitism in mammal-associated mites of the Psoroptidia group (Acari: Astigmata). Entomological Review, 9, 1206-1215. DOI: 10.1134/S001387381109 0168 .

Fain A. 1973a. Diagnoses d'Acariens nouveaux (Listrophoridea et Myobiidae) Revue de Zoologie et de Botanique africaines, 87, 330-332.

Fain A. 1973b. Les Listrophorides d'Amerique Neotropicale (Acarina: Sarcoptiformes). 1. Familles Listrophoridae et Chirodiscidae. Bulletin de l'Institut Royal des Sciences Naturelles de Belgique, 49, 1-149.

Fain A., Estebanes M.-L. 1996. New fur mites of the family Listrophoridae (Acari: Astigmata) from Mexico. International Journal of Acarology, 22, 181-186.

Fain A., Hyland K. 1974. The listrophorid mites in North America. II. The Family Listrophoridae Megnin \& Trouessart (Acarina, Sarcoptiformes). Bulletin de l'Institut Royal des Sciences $\mathrm{Na}$ turelles de Belgique, 50, 1-69.

Fain A., Lukoschus F.S. 1982. Diagnoses de nouveaux Listrophorides neotropicaux. Bulletin and Annales de la Societe Royale Entomologie Belgique, 118, 100-101.

Received: March 24, 2014

Revised: May 9, 2014

Accepted for publication: June 27, 2014
Fain A., Lukoschus F.S. 1984. New observations on the genus Prolistrophorus Fain, 1970 (Acari: Astigmata: Listrophoridae). Systematic Parasitology, 6, 161-185.

Fain A., Zanatta-Coutinho M.T., Fonseca M.T. 1996b. Observations on a small collection of mites (Acari) parasitic on mammals from Brazil. Bulletin de l'Institut Royal des Sciences Naturelles de Belgique, 66, 57-63.

Grandjean F. 1939. La chaetotaxie des pattes chez les Acaridiae. Bulletin de la Societe Zoologique de France, 64, 50-60.

Griffiths D.A., Atyeo W.T., Norton R.A., Lynch C.A. 1990. The idiosomal chaetotaxy of astigmatid mites. Journal of Zoology (London), 220, 1-32. DOI: 10.1111/j.1469-7998.1990.tb04291.x.

Hirst S. 1921. On some new or little known acari, mostly parasitic in man. Proceedings of the Zoological Society of London, 91, 375-378.

Musser G.G., Carleton M.D. 2005. Superfamily Muroidea. In: (Eds. D.E. Wilson and M.D. Reeder, 3rd ed.) Mammal species of the world. A taxonomic and geographic reference. Johns Hopkins University Press, Baltimore, 894-1531.

Norton R.A. 1998. Morphological evidence for the evolutionary origin of Astigmata (Acari: Acariformes). Experimental and Applied Acarology, 22, 559-594.

Radford C. 1954. Three new species of fur mites. Rivista di Parasitologia , 15, 593-599.

Sikora B., Bochkov A.V. 2012. Fur mites of the family Listrophoridae (Acariformes: Sarcoptoidea) associated with South American sigmodontine rodents (Cricetidae: Sigmodontinae). Acta Parasitologica, 57, 388-396. DOI: 10.2478/s11686-012-0046-1. 